\title{
Interactive comment on "Volume and temperature transports through the main Arctic Gateways: A comparative study between an ocean reanalysis and mooring-derived data" by Marianne Pietschnig et al.
}

\author{
M. Hecht (Editor) \\ mhecht@lanl.gov \\ Received and published: 14 March 2018
}

Dear Authors, I can see from your reply that you do understand Dr. Schauer's point. As Referee \#1 emphasizes, it will be important to better weave that understanding into the presentation of your findings when revising.

Referee \#2 provides a specific list of ways in the which they believe the paper may be improved. Please consider this list carefully as you decide how to revise.

I wish you the best with your revision. If a bit more time is needed, don't hesitate to 
ask.

Sincerely yours, -Matthew Hecht

OSD

Interactive comment on Ocean Sci. Discuss., https://doi.org/10.5194/os-2017-98, 2017.

Interactive

comment 